\section{ARCTIC AND ANTARCTIC}

\section{Arctic Research}

The Current Status of Research and Some Immediate Problems in the North American Arctic and Subarctic. Edited by Diana Rowley. (Special publication No. 2 of the Arctic Institute of North America. Reprinted from Arctic, Vol. 7, Nos. 3 and 4.) Pp. 261. (Montreal : Arctic Institute of North America, 1955.) 3.50 dollars.

Arctic Frontiers

United States Explorations in the Far North. By Dr. John Edwards Caswell. Pp. xv $+232+16$ plates. (Norman, Oklahoma: University of Oklahoma Press, 1956.) 3.75 dollars.

Men against the Frozen North

By Ritchie Calder. Pp. $279+15$ plates. (London: George Allen and Unwin, Ltd. ; Toronto : Thomas Nelson and Sons (Canada), Ltd., 1957.) $16 s$. net.

\section{Spring on an Arctic Island}

By Katharine Scherman. Pp. xvi $+331+12$ plates. (London: Victor Gollancz, Ltd., 1956.) 18s. net.

$T$ HE higher latitudes, both north and south, in these days receive an amount and style of atten. tion which is not altogether in accord with reality. Vestigial glamour, lack of perspective, research progress, public ignorance and polar beauty, are among the attitudes which characterize, with varying degrees of helpfulness, the arctic literature of to-day. The present four volumes under review are diverse in worth, style, and subject, and all will find gratefu readers. But those readers will be distinctly varied in type and taste, some learned, others ignorant but eager to read if the fare is, as some would say, served in the contemporary manner. The first of these four volumes is an important work.

"Arctic Research" is a truly important compilation and reference book. Its twenty-six chapters, each with its list of references, are about equally divided between the physical, the biological and the social sciences. There is a most impressive list of field research projects sponsored by the Arctic Institute since its foundation.

This work was not intended to provide a complete picture of aretic research, not even of North American arctic research, at this date. That would have been a goal impossible of attainment. Rather was the attempt to define the present state of knowledge in a selected variety of fields where individuals of prominence are available to perform the task. The introduction is by the late Dr. R. C. Wallace, the executive director of the Arctic Institute from 1951 until his death in 1955. Dr. Wallace played a great and vigorous part in the continuing growth of this energetic joint Canadian and United States organization. But the brunt of the work, in the production of the volume and the assembling of the authors, is due to Mrs. Diana Rowley, the editor. Her task cannot have been easy : the result is admirable.

The chapters are naturally of varying quality, but in general it is distinctly high. Excessive verbosity, that intellectual disease of North America, has been fairly well controlled, though we are still presented with 'population enumeration' for 'census' and similar word wasters. The lists of references are not overloaded ; indeed, in a fow instances further references to the scientific literature of Europe might have been helpful.
Photographs are quite properly not numerous. There are four striking pictures of the retreat of the North Dawes glacier in Alaska between 1889 and 1950 , a total of 6,500 feet.

This admirable volume may well be compared with "Problems of Polar Research" issued as Special Publication No. 7 of the American Geographical Society in 1928. That earlier work had a long and useful life, and so will "Arctic Research".

"Arctic Frontiers" describes the period of United States arctic explorations from 1850 to Peary's return from the attainment of the North Pole very nearly fifty years ago. As the author says, "This is the narrative, not of isolated adventures, but of a movement". This is an interesting and useful introductory record of what was afoot and when. The reader may well feel that he is perusing the competent précis of an extensive narrative; and that seems indeed to be so, the background work being the same author's study of "The Utilization of the Scientific Reports of the United States Arctic Expeditions 1850-1909".

"Men against the Frozen North" is a successor to the same author's two similarly titled books where our species is set as an adversary of deserts and jungles. This is not the place for detail. The author travelled very widely over the northern parts of the American continent, the Arctic Archipelago and Arctic Ocean. He did so in a very short time, and he is a scientific journalist of enthusiasm, discernment and repute. He knows full well that a large fraction of the population must be tempted to read by devices such as the use of direct speech and minor jokes, and that then information can be inserted like the filling of a sandwich. As The Times commented upon the onstage disrobement of a revue star, "if you like that sort of thing ; it is extremely well done".

"Spring on an Arctic Island" is by a woman author who spent six weeks in 1954 on Bylot Island off Northern Baffin Island in $73^{\circ}$ north latitude. This is a simple, personal tale, well told by one to whom all was happy novelty. "Above all we got to know some Eskimos." There are some attractive photographs. G. C. L. Bertram

\section{POISONOUS PLANTS}

\section{The Toxic Plants of Western Australia}

By C. A. Gardner and H. W. Bennetts. Pp. xxx + $253+52$ coloured plates. (Perth: West Australian Newspapers, Ltd., 1956.) $\quad f(A) 2$ i0s.

HE rich and varied flora of Western Australia, which has so many affinities with the flora of the Cape in South Africa, is noted for the number of highly ornamental or beautiful plants that it contains. Unfortunately, it contains also a large number of species known to be poisonous. These have been the cause of loss and anxiety to stock-owners since the days of the earliest settlers. A great deal of knowledge regarding these harmful plants has been accumulated in recent years, thanks largely to the investigations of the two authors of this book. They have now produced, in a most scholarly fashion, what is the first comprehensive work on the poisonous plants of Western Australia. Both authors are eminent in their respective fields-botanical and veterinary-and together they have forraed an ideal partnership for work of this kind. It is to be hoped that the toxic 